\title{
Study Regarding the Financial Reporting of Intangible Assets. Case of Romanian Pharmaceutical Industry
}

\author{
Alina Gheorghe Ancuța ${ }^{1}$, Florentina Moisescu ${ }^{1}$, Florina Varlanuta ${ }^{1}$
}

\begin{abstract}
The accounting treatment of intangible assets is a particularly complex and important issue for today's economy, a knowledge based economy. For now days companies, these assets are inductors for success and an important factor for achieving competitive advantage. Also, these assets are an important part of the financial statements. With the increasing weight and importance of the intangible assets the need for financial information of financial statements'users has changed and the current accounting system makes it difficult to cope with these developments. Because of the uncertainty that strikes intangible assets, accounting cannot capture their growing importance. Accordingly investors and other users of financial statements may not receive complete and relevant information for decision making. Basic questions arise here: Does the accounting treatment of intangible assets affect the relevance of financial information? ; May this treatment cause a misallocation of resources? The weakness is that the current accounting system can not capture all significant intangible values. Along with trying to answer the above question the purpose of this paper is to present the accounting treatment related to intangible assets according to international financial reporting standards and to analyze to what extent the accounting treatment of intangible assets affect the relevance of financial information for Romanian pharmaceutical companies listed on the Bucharest Stock Exchange

The research was qualitative type, based on empirical data recorded on a sample of 5 Romanian pharmaceutical companies, listed on the Bucharest Stock Exchange. The qualitative side is given by the fact that the study is based on interpretation, explanation, understanding.
\end{abstract}

Keywords: intangible assets, LAS 38 valuation, financial reporting

\section{Introduction}

The nature of investments made by companies has changed dramatically in the last quarter century. Besides the classic investments in tangible assets such as equipment, machinery, equipment and installations, investments in intangible assets become particularly important. According to the Organization for Economic Cooperation and Development, in certain countries, such as USA, Finland and the UK, the investments in intangible assets exceeded the investments in tangible assets. On the other hand, global competition, new innovative business models, the increasing importance of the services sector have increased significances of intangible assets for companies, sectors and national economies (OECD, 2011). Currently, it is increasingly recognized the importance and contribution of elements such as employee skills, knowledge, intellectual 
property rights, relations with suppliers and customers, software licenses to business competitiveness.

This changes in the structure of investments, according to several economists, is the expression of the transition from industrial economy to knowledge economy and knowledge-based economy, intangible assets are considered the main source of economic added value (Blaug \& Lekha, 2009).

In this context, the evaluation of intangible assets or the financial reporting of intangible assets raises questions concerning the identification, evaluation and control.

Intangible assets are difficult to observe and evaluate. Terms such as "intangible assets", "intellectual capital" and "knowledge capital" are often used interchangeably. A study conducted at the request of the European Commission (Zambon, 2003), defined intangible assets as sources of non-physical expected future benefits. Lev (2001) defined the intangible assets as "rights on some future benefits that it does not have a physical form"

\section{Review of the literature}

In academic literature intangibles are defined in various ways. From an economic perspective, investments in intangible assets comprise digital information (software), innovative property (research and development expenses - applied or fundamental), economic competences such as organizational capital and human capital specific (Falk, 2013). From an accounting perspective, intangible assets include software, patents, copyrights, motion picture films, licenses, franchises, patterns, design, prototypes, etc., but exclude specific human capital (Falk, 2013).

Reporting of intangible assets raises three main issues: the definition, recognition and measurement of initial costs related intangible assets, recognition and measurement of intangible assets associated future costs.

International Accounting Standards (IAS 38) defines intangible assets as identifiable nonmonetary assets without physical substance. A more general definition is given by Lev (2001) according to which intangible assets are non-physical rights on future benefits. The most common examples are: software products, copyrights, patents, licenses, concessions, brands, reputation, market parties, relationships with suppliers and customers, etc. (Gîrbină \& Bunea, 2009).

Definition of intangible assets has evolved in recent years, in order to provide a better understanding of the concept, to allow a proper evaluation of intangible investments and to facilitate communication between researchers, businessmen, financial analysts. It is generally considered that intangible assets have no physical substance and are linked to the legal rights they confer (trademarks, copyrights, patents, etc.) (Gîrbină \& Bunea, 2009). This assets are also defined as resources controlled by the enterprise as a result of past events and from which future economic benefits are expected to obtain.

By putting together all the elements, we find that the existence of intangible assets is related to fulfilment of the following four criteria: identifiable, lack of physical substance, control of the asset and future economic benefits from the use of the asset.

Not all the items listed above fulfil with the definition of intangible assets. The most important are the identifiability, the lack of physical substance, control and reliability assessment of future economic benefits. 
Intangible assets can be classified according to several criteria, but usually from the perspective of accounting valuation there are three categories: expences of research and development, goodwill and other intangible assets such as concessions, patents, licenses, etc.

If the lack physical substance is understandable, the criterion of being identifiable is problematic. So the following question arises: How do we identify an intangible asset?.

According to IAS 38, an asset is considered identifiable if it is distinguished from goodwill. Goodwill could be recognized in a business combination is an asset representing the future economic benefits arising from other assets acquired in a business combination are not individually identified and separately recognized. Goodwill in a business combination represents any excess of acquisition costs over the share in identifiable assets and liabilities of the owner, acquired at fair value exchange transaction date. Otherwise, the goodwill exceeds the amount of a fair paid amount of net assets of the acquired company. Goodwill is subject to a different standard IFRS 3 "Business Combinations".

An intangible asset arising from contractual or other legal rights and this is a feature that distinguishes it from goodwill. The value of goodwill is apparent from the collection of assets that make up a merged or acquired entity created by aggregating the value of the collection of assets through a business combination. Goodwill in a business combination as an asset recognized can not be identified individually and separately.

In other words, an intangible asset is identifiable if one of two conditions is met:

- The asset is individually identified and separated from the entity and sold, transferred through a license agreement, rented or exchanged, either individually or together with another contract with an asset or liability identifiable regardless of the entities' intention to do so either,

- The assets arises from contractual or other legal rights, regardless of whether those rights are transferable or separable from the entity or other rights.

In recognition of intangible assets acquired separately judgment must be present to assess the degree of confidence attached to the future economic benefits attributable to the use of the asset on the basis of available evidence at the time of initial recognition, the greater need for external evidence.

The control of an intangible asset is exercised, if the entity has the ability to obtain future economic benefits and to restrict access to future benefits for other entities supported by legal rights in court. Otherwise control is difficult to demonstrate. Legal rights are not a sine-quanon condition to control. There are other ways to control the future benefits. For example technical knowledge can generate future economic benefits. This knowledge can be protected by copyright, or a trade agreement, or legal obligation of employees to maintain confidentiality.

If an entity has skilled personnel through training and additional training that could generate future economic benefits. However it does not have enough control over future benefits for these items met in the definition of an intangible asset with no royalties.

The portfolio of customers, market shares, customer relationships and loyalty, to meet the definition of an intangible asset, the existence of legal rights to protect customer relationships, exchange transactions capable of separation gives definition and recognition criteria of an intangible asset. Recognition of an asset in the balance sheet 
appears to a probable future economic benefits to flow to the entity and the asset has a cost or value that can be reliable. The entity shall exercise control over the asset's future economic benefits. Asset Control is defined as the power to obtain future economic benefits flowing from it. Future economic benefits arising from intangible assets include income from the sale of products or services, savings, cost reduction, etc.

Recognition of intangible assets reflects a compromise between relevance and reliability, conservatism and caution (Høegh-Krohn \& Knivsflå, 2000). International accounting standards provide recognition criteria for each of the three categories of property mentioned above.

Recognition of an intangible asset in the balance sheet appears when it is probable that future economic benefits to flow to the entity and the asset has a cost or a value that can reliably measured.

In the case of separate acquisition the probability criterion it is always considered fulfilled. In addition, the cost of an intangible asset can be reliably measured, consisting in the purchase price plus other direct costs attributable to the assets.

In case of acquisition as part of a business combination, the situation is more complex and subject to IFRS 3. Therefore, in accordance with IAS 38 and IFRS 3, an acquirer recognizes at the acquisition date, separately from goodwill, an intangible asset if the asset's fair value can be measured reliably, irrespective of whether the asset had been recognized by the acquire before the business combination. A delicate problem, related to intangible assets is recognition of internally generated intangible assets (Gîrbină \& Bunea, 2009). To determine if internally generated intangible assets meet the criteria for recognition, companies classify the process of obtaining these assets in a research phase and a development phase.

Research phase only generates expenses. In this phase no intangible asset can be recognized because it can demonstrate that it will generate future benefits (Moisescu, 2010). Examples of research: obtaining new knowledge; final selection for applications that generate new knowledge; the search for alternatives for materials, devices, instruments, products, processes, systems or services; the formulation, design, evaluation and final selection of possible alternatives for materials, devices, tools, products, processes, systems or services or improved.

In the development phase, the entity may identify an intangible asset and demonstrate that it meets the definition and recognition criteria. Recognition of an intangible asset occurs if and only if the entity can demonstrate the following criteria to be met cumulatively: technical feasibility completion of the asset to be available for use or sale; The intention to complete the asset and use or sell it; Ability to use or sell the intangible asset; How the asset will generate future economic benefits by the existence of a market for active production or use internally estimate; Availability of technical resources, financial and other assets to complete the development and to use or sell the asset; Ability to credible assessment of costs attributable to the intangible asset during its development phase.

The development phase of a project is further advanced than the research phase. In certain circumstances the entity may identify an intangible asset and be skilful enough to demonstrate that it will generate future economic benefits possible. 
To assess the entity's future economic benefits from an internally generated intangible assets use is made of the principles of IAS 36 Impairment of Assets. Specifically if the asset will generate future economic benefits only in combination with other assets, the entity applies the concept of unity cash IAS 36.

Examples of development activities are: design, construction and testing of models, prototypes before production and use; through new technology entity projecting tools, templates, molds and dies; design, construction and operation of a factory pilot - not of a scale economically feasible for commercial production; and design, construction and testing of a chosen alternative for materials, devices, products, processes, systems or services or enhancements.

Under development costs trademarks, technical boxes, publication titles, customer lists and items similar in substance generated internally can not be distinguished from the cost development as a whole. In conclusion these items are not recognized as intangible assets.

If the enterprise can not distinguish the two phases to create an intangible asset, it treats that expense of the project as if it were done only in the research phase.

Basically there are three possibilities of reporting changes in the value of intangible assets: depreciation, impairment and revaluation.

IAS no. 38 sets the benchmark treatment and alternate on the balance sheet valuation of intangible assets. In the cost model after initial recognition of an intangible asset shall be measured at its cost less any accumulated depreciation and less any loss depreciate. Reevaluation is an alternative treatment to estimate the value of intangible assets when the economy is affected by inflation. The entire class of intangible assets should be revalued simultaneously rejecting selective revaluation of values "resulting from the combination of costs and values" as at different dates. This model does not allow: revaluation of intangible assets that have not previously been recognized as assets; initial recognition of intangible assets at amounts other than cost. The model can be applied to an intangible asset that was received through a government grant and reputable nominal value. Reevaluation provides that after the initial recognition of an intangible asset, to be presented at revalued amount based on fair value at the time of revaluation less accumulated depreciation and impairment losses. The fair value must be determined by reference to an active market.

\section{Research hypotheses}

Based on the above considerations, the questions from which I start to approach the research are "Does the accounting treatment of internally generated intangible assets affect the relevance of financial information?" and "Does the accounting treatment of internally generated intangible assets leads to a misallocation of resources?"

Most investment in intangibles are recorded as expenses as soon as they are incurred (Galbreath \& Galvin, 2006), according to the accounting treatment prescribed by IAS 38. On the other hand, the benefits of these investments are recorded later (Siegel \& Borgia, 2007). As a result, the accounting principle of connecting expenses to income is severely biased and could unfavourably affect the value relevance of financial information 
(income, cash flows and the carrying amount). Given this problem, many researchers have tried to examine the association between financial information contained in the financial statements and market value using various valuation models of the company. In this context, Lev and Zarowin concluded, using a sample of US firms, that the usefulness of financial information to investors has dropped significantly in the last two decades (Baruch \& Paul, 1999). The authors mention that the inability to recognize the intangible investment information as an assets, especially the intellectual capital of a company, as causing this loss in value relevance of financial information.

Other authors have also reported the existence of a decline in the financial result and value relevance of book values in explaining the market value of US companies. According to these authors, the decrease is related, in fact, to high costs associated with intangible investments. These intangible investments can not be capitalized and recorded as assets in the balance sheet, it is possible only recognize them as expenses. Thus, the impact on book value is negative (Zéghal \& Maaloul, 2011).

In another study, conducted in Taiwan, Yao and Liang confirmed the results of previous studies, using a sample of Taiwanese high-tech companies. Indeed, their results show that traditional financial measures provided no significant explanatory power regarding the company's value (Liang \& Yao, 2005).

However, there are papers which reject the hypothesis that intangibility reduces the value relevance of financial information. The obtained results support the idea that financial statements are less relevant for high-tech firms than for traditional companies (Zéghal \& Maaloul, 2011). Likewise, other authors have shown that the relationship between market value and traditional financial variables differ in present period from the previous period, and the ability of financial variables traditional explain market value decreased for those firms that are new Economy.

Consequently we can say that the results of these studies are mixed. There is no uniform opinion on the relevance of financial information. The accounting treatment of internally generated intangible assets, coupled with an inefficient system of assessment has significant implications for companies, shareholders and society as a whole.

Intangible assets were subject to a survey by TNS Political \& Social at the request of the European Commission - Directorate General for Enterprise and Industry, entitled "The investments in intangible: economic and innovation engine for growth" (2013). The study focused on the behavior of enterprises in investment in intangible assets. In this study they were examined issues such as intangible asset types that companies prefer to invest, financing - from internal resources or external sources, the reasons why companies invest in intangible assets, etc.

According to the study, company's priorities in terms of the intangible assets are customized IT solutions and services, reducing production costs, developing new products and services and increase labor productivity. In general the companies prefer to invest in internally generated intangible assets as the expense of acquired and the three activities that are most likely to be the subject of such investments are optimizing operating processes, staff training, company reputation and trademark development.

Considering that the most important share of investments in intangible assets is represented by the internally generated, companies can suffer a range of socio-economic consequences if they fail to provide adequate and relevant information for shareholders 
and potential investors. These consequences, such as information asymmetry, high cost of capital, high risk, lack of liquidity, can lead to misallocation of resources in the capital market. Moreover, financial accounting scientific literature acknowledged the existence of market imperfections due to information asymmetry. In this context, inaccurate reporting of intangible assets in the financial statements, in addition to their specificity for the company, creates high levels of asymmetric information between internal and external investors. Insider's investors generally hold the advantage of a plus of information regarding the company and intangible assets. This advantage allows them to make favorable adjustments in their portfolio at the expense of outside investors. Due to their disadvantage, foreign investors will demand, in general, a higher rate of return on invested capital. As a result of the inadequate accounting treatment of internally generated assets and the negative consequences that could result from this, international accounting bodies have made considerable efforts to improve the quality of accounting information. They designed models and guides for additional information to be reported in the notes to the financial statements. They have particular regard to non-financial reporting information related to intangible assets. A sensitive element from investment is the intangible costs of research and development (Michael \& Mihalciuc, 2011). Most Romanian companies believe that research and development is a key element of economic competitiveness, but, however, in the whole country, investments in R \& D represent only $0.4 \%$ of GDP, the lowest rate in the 10 countries Central who participated in the study of CE Deloitte Corporate R \& D Report 2014. According to the same study $71 \%$ of local companies said they plan to increase spending on research and development in the coming years. On the other hand according to data presented by the National Institute of Statistics, the GDP share allocation for R\&D activity in 2014 was located at the lowest level since 2005, 0.38\% of GDP. This value puts Romania in the last position of EU Member States and is far away from the $2 \%$ already achieved the European average. There is a major change to the business environment, where the interest for R\&D is relatively small, but highly concentrated in a few areas such as automotive and IT sector.

Table no. 1 - Structure of expenses for R\&D component

\begin{tabular}{|l|l|l|l|l|l|l|l|l|l|}
\hline Anul & $\mathbf{2 0 0 6}$ & $\mathbf{2 0 0 7}$ & $\mathbf{2 0 0 8}$ & $\mathbf{2 0 0 9}$ & $\mathbf{2 0 1 0}$ & $\mathbf{2 0 1 1}$ & $\mathbf{2 0 1 2}$ & $\mathbf{2 0 1 3}$ & $\mathbf{2 0 1 4}$ \\
\hline Share of GDP (\%) & 0,46 & 0,54 & 0,59 & 0,48 & 0,47 & 0,48 & 0,49 & 0,39 & 0,38 \\
\hline $\begin{array}{l}\text { allocated amounts } \\
\text { (mld lei) }\end{array}$ & 1,57 & 2,18 & 2,51 & 2,36 & 2,41 & 2,79 & 2,36 & 2,46 & 2,55 \\
\hline Of which (\%) & & & & & & & & & \\
\hline Personnal & 51,9 & 53,3 & 48,8 & 57,8 & 57,1 & 53,9 & 55,5 & 56,4 & 54,9 \\
\hline Material costs & 24,8 & 21,2 & 26,1 & 19,3 & 15,6 & 15 & 12,5 & 11,7 & 12,6 \\
\hline Other costs & 23,3 & 25,5 & 25,1 & 22,9 & 27,3 & 31,1 & 32 & 31 & 32,5 \\
\hline
\end{tabular}

Source-http:// wmm.insse.ro/cms/ro/content/ activity of research and development

While the average amounts invested in research and development reach an average of $2 \%$ of GDP in the European Union (maximum $4 \%$ for Sweden and Finland), in Romania these are at around 0,3 - 0,4\% a level equal to that of Poland and Slovakia and half of that of Hungary and the Czech Republic. The number of researchers in Romania was reduced dramatically since 1990 and currently stands at barely a third of the EU 
average. The private sector performs modest in terms of innovations. The European Union still more than half of research and development contribution is given by private companies, while in Romania it is only $23 \%$, mostly constituted by public funds.

Table no. 2 - Total expenditure in research and development, the finance and sector performance in 2014 (millions lei)

\begin{tabular}{|l|l|l|l|l|l|}
\hline $\begin{array}{c}\text { Sector of } \\
\text { performance } \\
\text { founding of }\end{array}$ & Total & $\begin{array}{l}\text { Business } \\
\text { sector }\end{array}$ & $\begin{array}{l}\text { Government } \\
\text { sector }\end{array}$ & $\begin{array}{l}\text { Higher } \\
\text { education } \\
\text { sector }\end{array}$ & $\begin{array}{l}\text { Private non } \\
\text { benefit } \\
\text { sector }\end{array}$ \\
\hline TOTAL & 2555,7 & 1059,4 & 1097,8 & 389,0 & 9,5 \\
\hline Companies & 841,2 & 627,5 & 186,7 & 26,9 & 0,1 \\
\hline Public funds & 1240,8 & 201,4 & 818,7 & 214,4 & 6,3 \\
\hline Privat - non-profit & 2,4 & 0,2 & 0,6 & 1,0 & 0,6 \\
\hline Higher education & 36,9 & 1,9 & 1,2 & 33,8 & \\
\hline Foreign & 434,4 & 228,4 & 90,6 & 112,9 & 2,5 \\
\hline
\end{tabular}

source - http:// wmw.insse.ro/ cms/ro/content/ activity of research and development

After funding sources of total R \& D expenses in 2014, public funds had the highest share $(48.6 \%)$, followed by private funds - from the companies $(32.9 \%)$.

\section{Study on financial reporting of intangible assets by pharmaceutical companies listed on BSE}

The pharmaceutical industry is a sector where $\mathrm{R} \& \mathrm{D}$ costs, intellectual property rights, regulation, procedure for authorizing medicinal products, etc. are very important elements. If the firm performs a new drug patent and its implications are significant for company value. In our approach, our objective was to analyse if the pharmaceutical sector companies listed on BSE comply with the minimum criteria on the inclusion of information in the notes of significant items related to intangible assets required by accounting regulations harmonized with IAS / IFRS. In order to grasp the practical issues on reporting intangible assets we analyzed the published financial statements, the notes and the auditors reports for Romanian listed pharmaceutical companies. The source of data is the information being published www.bvb.ro and individual sites companies. In Romania there are 170 companies active in the production of drugs. Of these only five are listed companies. The 5 companies which are the subject of the case study are: Zentiva, Antibiotice, Biofarm, Meduman and Sintofarm. These companies have as main activity is the manufacture of basic pharmaceutical products (CAEN 2110) and manufacture of pharmaceutical preparations. 
Table no. 3 -Intangible assets reporting in annual financial statements (thousand euro)

\begin{tabular}{|l|l|l|l|l|l|}
\hline Company & $\mathbf{2 0 1 4}$ & $\mathbf{2 0 1 3}$ & $\mathbf{2 0 1 2}$ & $\mathbf{2 0 1 1}$ & $\mathbf{2 0 1 0}$ \\
\hline Zentiva SA & 135 & 81 & 94 & 167 & 111 \\
\hline Antibiotice SA & 1.769 & 1.364 & 1.103 & 382 & 464 \\
\hline Biofarm SA & 45 & 56 & 44 & 201 & 272 \\
\hline Meduman SA & 242 & 243 & 245 & 281 & 338 \\
\hline Sintofarm SA & 5 & 17 & 31 & 5 & 3 \\
\hline
\end{tabular}

The highest values of the intangible assets they report company Antobiotice SA and lowest values are reported Sintofarm (table no. 3). The highest proportion of intangible assets to total assets are recorded Meduman SA (table no. 4).

Table no. 4 - The share of intangible assets in total assets reported (\%)

\begin{tabular}{|l|l|l|l|l|l|}
\hline Company & $\mathbf{2 0 1 4}$ & $\mathbf{2 0 1 3}$ & $\mathbf{2 0 1 2}$ & $\mathbf{2 0 1 1}$ & $\mathbf{2 0 1 0}$ \\
\hline Zentiva SA & $0,16 \%$ & $0,10 \%$ & $0,13 \%$ & $0,21 \%$ & $0,12 \%$ \\
\hline Antibiotice SA & $1,57 \%$ & $1,20 \%$ & $0,95 \%$ & $0,37 \%$ & $0,51 \%$ \\
\hline Biofarm SA & $0,10 \%$ & $0,12 \%$ & $0,10 \%$ & $0,47 \%$ & $0,69 \%$ \\
\hline Meduman SA & $8,83 \%$ & $10,66 \%$ & $10,87 \%$ & $11,73 \%$ & $15,45 \%$ \\
\hline Sintofarm SA & $0,17 \%$ & $0,60 \%$ & $1,20 \%$ & $0,21 \%$ & $0,13 \%$ \\
\hline
\end{tabular}

In order to achieve the stated objectives, my goal was to find in the annual financial reports answers to following questions:

1. Does the company shows the movement of intangibles, both increases and decreases during the period, offering details for dynamics of intangible assets?

2. Does the entity discloses adjustments related to intangible assets impairment accompanied by a brief explanation of causes related?

3. Does the entity mentions the amortization method of intangible assets for each category?

4. Does the company disclose any details regarding the $\mathrm{R} \& \mathrm{D}$ ?

5. Does the company gives details of intangible assets in progress?

6. Are the information on intangible assets are presented in the annual report, prepared in accordance with the regulation no. 1/2006 NSC?

Following the qualitative analysis carried out, we found that the information gathered shall be briefly presented, that does not follow the line drawn by IAS 38 and does not lead to comprehensive information to investors. For example, they are given information regarding the movements of intangible assets, gains and reduction, but without providing details on the dynamics and structure. I found no information regarding the adjustments for depreciation or amortization methods. There are offered minimal information on research and development. The companies included in Note 1 "assets" on the numerical data increases, disposals and transfers of intangible assets during the year, but the figures are rarely accompanied by explanations concerning transactions. Values shown are not explained or interpreted. Some companies mentioned in note "principles, policies and 
accounting methods" intangible items, specifying the method and amortization period. Similarly, for intangible assets in progress are offered values, but are not offered details on these items. Information on intangible assets in the annual report, prepared in accordance with provisions of the Regulation contains basic information and do not contain any information referitoarela intangibles. The research was qualitative in nature, based on empiric data recorded on a sample of five Romanian companies listed on the Bucharest Stock Exchange. Qualitative research side is the fact that the study is based on interpretation, explanation, understanding. In literature and quantitative models were developed to study intangible assets. These models resort to quantitative measurement, quantification, digital data of phenomena which will be studied.

\section{Conclusion}

Intangible assets are characterized by delicate issues on the assessment and recognition in the financial statements. As a result it was impossible to develop an overarching accounting standard. IAS 38 is an attempt to impose a uniform set of rules regarding intangible assets. IAS 38 imposes strict limits regarding certain assets, particularly internally generated. However the argument that it can not establish a relationship between the cost of the asset and future income streams is applicable to tangible assets. Exclusion rule is internally generated intangible assets and supersede the tests for recognition of these assets.

The issue of financial and non-financial reporting of intangible assets attracted the interest of many researchers worldwide. Unfortunately there is very little literature concerns about the financial and non-financial reporting of intangible assets by Romanian firms.

Future research directions will consider extending the analysis to a sample Romanian companies and identify factors that influence the amount of information published by the companies on the Romanian intangible assets.

\section{References}

Ahmed, K., \& Falkb, H. (2006). The value relevance of management's research and development reporting choice: evidence from Australia. Journal of Accounting and Public Policy, 25(3), 231-264.

Baruch, L. (2001). Intangibles - Management, Measurement, and Reporting. Washington DC: Bookings Institution Press.

Baruch, L., \& Paul, Z. (1999). The Boundaries of Financial Reporting and hoe to Extend Them. Journal of Accounting Research , 37(2), 353-385.

Blaug, R., \& Lekhi, R. (2009). Accounting for intangibles: Financial reporting and value creation în the knowledge economy - A Research Report for The Work Foundation's Knowledge Economy Programme. The Work Foundation.

Clarke, T., \& Stewart, C. (2000). Changing Paradigms: The Transformation of Management Knowledge for the 21st Century. Harpercollins Pub Ltd.

Falk, M. (2013), New empirical findings for international investment în intangible assets, Working Paper no 30, www.foreurope.eu

Galbreath, J., \& Galvin, P. (2006). Firm factors, industry structure and performance variation: New empirical evidence to a classic debate. Journal of Business Research, 61(2), 109-117.

Gîrbină, M., \& Bunea, Ș. (2009). Sinteze, studii de caz și teste grilă privind aplicarea IAS (revizuite) - IFRS (Vol. 1). București: CECCAR. 
Høegh-Krohn, N., \& Knivsflå, K. (2000). Accounting for Intangible Assets în Scandinavia, the UK, the US, and by the IASC: Challenges and a Solution. The International Journal of Accounting, 35(2), 243265.

Huang, S.-M., Ou, C.-S., Chen, C.-M., \& Lin, B. (2006). An empirical study of relationship between IT investment and firm performance: A resource-based perspective. European Journal of Operational Research, 173(3), 984-999.

Liang, C.-J., \& Yao, M.-L. (2005). The Value-Relevance of Financial and Nonfinancial InformationEvidence from Taiwan's Information Electronics Industry. Review of Quantitative Finance and Accounting, 24(2), 135-157.

Lev, B. (2001). Intangibles: Management, Measuring and Recording.Washington, DC.: Brookings Institution press. p5.

McGee, R. W. (2008). Corporate Governance în Transition Economies. (M. W. Robert, Ed.) Florida: Springer.

Mihai, I.O., Mihalciuc C. (2011), "Accounting treatment for R\&D activities in accordance with IFRS and Romanian Legislation." The USV Annals of Economics and Public Administration 11.1: 226-236.

Moisescu F. (2010) Convergente contabile internationale, Editura Europlus , Galați, pg 25

Rezaee, Z. (2009). Corporate Governance and Ethics. John Wiley and Sons.

Siegel, P., \& Borgia, C. (2007). The Measurement and Recognition of Intangible Assets . Journal of Business and Public Affairs, 1(1).

Spanos, L. J. (2005). Corporate Governance în Greece: Developments and Policy Implications. Corporate Governance, 5(1), 15-30.

Zambon, S. (2003). Study on the Measurement of Intangible Assets and Associated Reporting Practices, Commission of the European Communities, Enterprise Directorate General, Brussels.

Zéghal, D., \& Maaloul, A. (2011). The accounting treatment of intangibles - A critical review of the literature. Accounting Forum, 35, 262- 274.

*** OECD. (2011). New sources of growth: intangible assets.

*** TNS Political \& Social, (2013). Investing în Intangibles: Economic Assets and Innovation Drivers for Growth. European Commision. 